\title{
Wavelength conversion technology
}

\section{Stubkjær, Kristian}

\section{Published in:}

Technical Digest Optical Fiber Communication Conference and Exhibit

Link to article, DOI:

10.1109/OFC.1998.657239

Publication date:

1998

\section{Document Version}

Publisher's PDF, also known as Version of record

Link back to DTU Orbit

\section{Citation (APA):}

Stubkjær, K. (1998). Wavelength conversion technology. In Technical Digest Optical Fiber Communication Conference and Exhibit IEEE. https://doi.org/10.1109/OFC.1998.657239

\section{General rights}

Copyright and moral rights for the publications made accessible in the public portal are retained by the authors and/or other copyright owners and it is a condition of accessing publications that users recognise and abide by the legal requirements associated with these rights.

- Users may download and print one copy of any publication from the public portal for the purpose of private study or research.

- You may not further distribute the material or use it for any profit-making activity or commercial gain

- You may freely distribute the URL identifying the publication in the public portal

If you believe that this document breaches copyright please contact us providing details, and we will remove access to the work immediately and investigate your claim 
multiplexing transmission and the wavelength-routing capabilities of paths.

To develop robust and efficient networks utilizing these new tech nologies, new network architectures and operation systems need to be developed. Graceful network introduction is also an important point to be considered. Therefore, the maximum commonality with already established SDH networks should be retained and the technologies must be fully applied. As a result, optical paths should accommodate Virtual Containers (VC-4-16c etc.), because this enables very efficient and robust networking in terms of providing the networks with QoS monitoring capability of the optical layer and exploiting the overhead processing ISIs already developed for SDH. New photonic network-node interfaces need to be created and standardized.

Transparency is one important feature of photonic networks, but will not always be necessary. This is because more transparency lowers the robustness of the network because only rather limited performance measurement/monitoring capabilities such as optical power level measurements can be realized in a transparent network. Thus, the important thing is that different adaptation functions need to be developed in accordance with the client signals of the optical paths (channels) or in response to the transparency required for the optical path; network development should allow different choices to be made.

Photonic network technologies will enable a network paradigm shift to bandwidth-abundant and ubiquitous multimedia networks. Toward this goal, NTT is now developing testbeds for the field tests to be conducted from 1998 to 2000 . These technologies will first be introduced in our network for the provision of large bandwidth and very costeffective ATM leased line services.

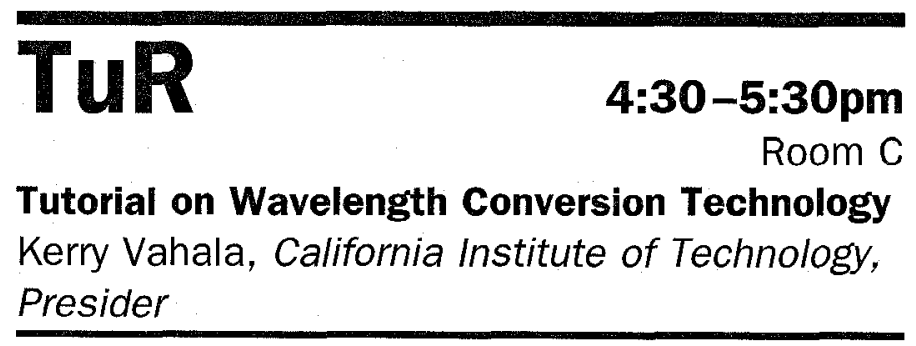

TuR (Tutorial)

$4: 30 \mathrm{pm}$

\section{Wavelength conversion technology}

Kristian E. Stubkjaer, Technical University of Denmark, Department of Electromagnetic Systems, Bldg. 348, Lyngby, DK-2800, Denmark

Optical wavelength conversion is currently attracting much interest. This is because it enables full flexibility and eases management of WDM networks. The tutorial will review existing and potential application areas. Examples of node architectures and network demonstrators that use wavelength conversion will be given. In the demonstrators that are built today, the main function of the wavelength converter is to solve wavelength contention, but advanced schemes in which the converter performs space switching functions are also foreseen.

Next, we will carefully examine the techniques available for wavelength conversion. The converters fall into four groups:

- Opto-electronic converters,

- Laser converters,

- Coherent converters (four wave mixing and difference frequency generation),

- Converters based on optically controlled optical gates.

Opto-electronic conversion is a straight forward solution that is already used in some WDM systems. The last three converter types are all-optical that avoid opto-electronic translation. They are still subject to research and development and show fine progress. The physical mechanisms behind the all-optical converters will be discussed to allow understanding of their advantages and limitations. For the different converter types we examine properties such as complexity, bit rate capability, input power dynamic range, power efficiency, noise and signal regeneration. Moreover, prospects for their future development will be discussed. 